\title{
A maturação da capacidade de metamorfose no jogo mimicry
}

The maturation of metamorphosis capacity in the mimicrygame

Theda Cabrera 


\section{Resumo}

Este artigo tem como base minha experiência empírica como artista-educadora e pesquisadora (financiamento Capes 2011-2013; Fapesp 2013-2015 e 2016-2017). Pretende gerar uma reflexão sobre o jogo de categoria mimicry (Caillois, 1990) em suas variadas gradações e apontar a importância da observação e intervenção artístico-pedagógica diante de diferentes estágios da capacidade de metamorfose do jogador (Lopes, 1989). Longe de excluir recursos já consagrados noteatro-educação, busca contextualizá- los num quadro mais abrangente de referências, na práxis de uma ético-poética (Cabrera, 2015) na expressão dramática.

Palavras-chave: Teatro e educação; jogos dramáticos; instrução em grupo; mediação pedagógica; formação de professores

\section{Abstract}

This paper is based on my empirical experience as an artist-educator and researcher (funding Capes 2011-2013; Fapesp 2013-2015 and 2016-2017). Aims to generate a reflection on the mimicry play category (Caillois, 1990) in its various gradations and highlight the importance of observation and intervention artistic-pedagogical in the different stages of the metamorphosis capacity of the player (Lopes, 1989). Far from dismissing resources already enshrined in the theater-education, seeks contextualize them in a broader frame of reference, in the praxis of an ethical-poetic (Cabrera, 2015) in dramatic expression.

Keywords: Theater and education; dramatic play; group instruction; pedagogical mediation; teacher education
ISSN: 1414.5731

E-ISSN: 2358.6958

1 Bacharel e Mestre em Artes Cênicas pela Universidade Estadual de Campinas (UNICAMP). Doutora (Bolsa Capes 2011-2013/ Fapesp 2013-2015) e Pós-Doutoranda (Bolsa Fapesp 2016-2017) em Educação pela Universidade de São Paulo (USP). thedacabrera@yahoo.com.br 


\section{Introdução}

Este artigo tem como base meu trabalho como artista-educadora e pesquisadora desde 2001, como professora de teatro em cursos livres e técnicos de teatro em Campinas/ SP (2000-2004) e como formadora de educadores e arte-educadores junto a ONG Cenpec em São Paulo /SP (2005), Programa Teia do Saber em Sorocaba/ SP (2006-2007) e curso de Licenciatura em Arte-Educação: Teatro da Universidade de Sorocaba/ SP (2005-2009). As questões do presente artigo tem se verticalizado nos últimos anos a partir de algumas experiências mais recentes: 1) com jovens graduandos de Pedagogia da Universidade de São Paulo, no âmbito do Núcleo de "dramatização de contos" do Laboratório Experimental de Arte-Educação e Cultura (Lab_Arte)- FE/ USP (2012-2014), no contexto da minha pesquisa de Doutorado em Educação (financiamento Capes 2011-2013-; Fapesp 2013-2015) e Pós- Doutorado em Educação (financiamento Fapesp 2016-2017) pela Faculdade de Educação da Universidade de São Paulo; 2) licenciandos em Arte-Teatro do Instituto de Artes da Universidade Estadual Paulista como professora substituta nas disciplinas "Prática de Ensino: Ensino de Artes"; "Prática de Ensino: Ensino de Artes Cênicas" e "Estágio Supervisionado" em 2015; 3) crianças e adolescentes entre 5 e 14 anos participantes do contexto de educação não-formal oferecida pelo Programa Piá- São Paulo/ SP em 2015, onde atuei como artista-educadora em Artes Integradas na Biblioteca Monteiro Lobato e 4) a convivência com minha filha, agora no auge das suas brincadeiras dramatizadas da primeira infância.

Toma também como referência textos pouco difundidos no Brasil atualmente, de artistas-educadores que observaram na prática certos aspectos do jogo dramático e que podem contribuir na reflexão sobre o fazer artístico-pedagógico com crianças, adolescentes, jovens e adultos não profissionais em espaços de educação formal e não-formal. Pretende também discutir com um olhar crítico uma bibliografia que, em parte, teve suas edições esgotadas, não-publicadas no Brasil ou pouco discutidas por aqui, mas que ainda ecoam na minha práxis e que acredito que possam trazer contribuições aos artistas-educadores contemporâneos. Apesar de adotar como referência bibliográfica alguns autores em que se observa vestígios piagetianos, discordo do fundo "evolucionista" agregado: nem sempre os estágios das crianças mais velhas são mais evoluídos do que os das crianças pequenas; nem sempre os homens ditos "primitivos" são menos "evoluídos" do que aqueles que vivem na sociedade urbana ocidental contemporânea, nem sempre a teoria contemporânea mais em voga precisa anular ou negar outros conhecimentos precedentes. Interessa principalmente refletir sobre a verificação na prática de teorias advindas, elas mesmas, da observação prática de outrem. Longe de replicar observações feitas em outros tempos e em outros contextos como aplicáveis ao instante de agora, interessa extrair o que há inspirador nelas para criar no presente práticas que atendam a outros tempos e outros contextos.

Adoto aqui a definição de Huizinga para jogo: é uma situação temporária, regrada, convencional, "que cria ordem e é ordem" (Huizinga, 1999, p. 13). E me refiro a um tipo específico de jogo, o jogo de categoria mimicry: um jogo que pede a aceitação 
temporária de uma ilusão na encarnação de um comportamento, portanto dando ao jogo caráter de mímica, disfarce, simulação, simulacro (Caillois, 1990).

Caillois (1990) reconhece o jogo como fenômeno antropológico e vê o jogo de simulação em inúmeros contextos, desde os mais simples aos mais complexos: desde as imitações infantis; brincadeiras com bonecas; máscaras e disfarces até o teatro e as artes do espetáculo em geral. Se aceitarmos como premissa esta observação de Caillois, podemos verificar diferentes gradações de jogo de categoria mimicry (Caillois, 1990) no contexto do teatro-educação presentes desde as brincadeiras dramatizadas mais simples das crianças pequenas (brincadeiras dramatizadas de fazde-conta) até as apresentações mais organizadas em torno do espetáculo teatral na escola. Tentando "desembaraçar os fios" (Pupo, 2005) do que se praticou e se pratica em termos de arte-educação no Brasil desde meados da década de 1960 até hoje no Brasil (Mate, 2010) podemos chegar a inferir que as manifestações dramáticas de não profissionais do jogo mimicry possuem gradações que englobam desde o jogo dramático espontâneo (Lopes, 1989), jogo dramático infantil (Leenhardt, 1977; Slade, 1978), teatro do oprimido (Boal, 1983, 1996, 2005) até o jogo teatral (Spolin, 1979, 1999, 2001). Longe de hierarquizar ou pretender dar um juízo de valor, cada uma destas gradações tem seu valor intrínseco e interessa aqui conhecer melhor algumas destas gradações.

Longe de buscar um

[...] modelo para tecer o curso da verdade (Lopes, 1989, p. 64), [...] não aceitamos partir de modelos esquemáticos montados através de técnicas predeterminadas (Lopes, 1989, p. 65) (...) [e] padronizadas que, por sua vez, causam uma visão simplista e simplificante do que possa ser a união de arte e educação num só movimento crítico (Lopes, 1989, p. 63).

As condições espaciais, temporais e humanas envolvidas neste processo precisam ser levadas em conta para a busca de recursos e ferramentas para lidar com as situações do presente no presente. É o momento da epifania, do agora-já, de aproveitar-se das oportunidades que surgem, das perguntas, conflitos, dificuldades vivenciadas como estímulos para a composição de propostas e de encaminhamentos. Aprendendo a jogar enquanto se joga, criando regras de jogo ao se deparar com a necessidade delas, liberar-se de convenções de outrora que não servem ao propósito de agora.

Mais do que defender uma linha ou um manual específico como guia do fazer teatral, interessa aqui dar subsídios para que, diante de cada jogador se possa reunir condições para que sua criatividade e capacidade de comunicação e expressão sejam cultivadas, independente de padrões estéticos ou poéticos impostos a priori. Em contraponto a uma pedagogicização escolarizante, a um "furor pedagógico" (Jung, 1986), interessa "fazer-se inteiramente para cada um segundo os caminhos de cada um" (Mounier, 1976, p. 130).

\section{O jogo dramático espontâneo e o jogo dramático infantil}

Na linhagem de arte-educadores que se interessaram pelo fenômeno antropo- 
lógico do jogo e que se dedicaram a diferentes abordagens do teatro na educação, alguns deles se dedicaram a descrever e estudar o jogo dramático da/ na criança, os processos de simbolização que se exteriorizam por meio da linguagem dramática e a importância destes processos cognitivos.

Interessa aqui citar a contribuição da brasileira Joana Lopes, que passou a dialogar com a pedagogia freiriana a partir da segunda metade da década de 1960, atuando como arte-educadora na Escola Experimental Vera Cruz e na Escola Renovada Gabriela Mistral. Também desenvolveu um trabalho na Escolinha de Arte de São Paulo, dirigida por Ana Mae Barbosa. Em 1969, a convite de Herbert de Souza, o Betinho, desenvolve um trabalho de teatro com operários no ABC paulista (Debértolis, 2002, p. 38). Como arte-educadora, a partir de 1969, Lopes catalisou outros artistas para compor o Gruparte - Teatro Educação de São Paulo, participou com uma instalação na Bienal de São Paulo de 1973 e desenvolveu uma série de ações de teatro-educação em Londrina (Debértolis, 2002, p. 39-43). São estas últimas experiências citadas que compõem a base para o livro "Pega teatro", que "sofreu muitas mortes e renascimentos" (Lopes, informação verbal, 1999) até ser editado em 1981 e reeditado em 1989. No capítulo "Somos todos atuantes, alguns serão atores de profissão" Lopes (1989) observou e descreve o que ela chama de jogo dramático espontâneo:

[...] compreendendo-o como manifestação espontânea de nossa potencialidade de comunicação. Da compreensão que surge, deverão também surgir técnicas e organizações que desdobrem a criatividade e a teatralidade do jogo dramático, no sentido de formas mais poéticas e mais comunicantes [...] (Lopes, 1989, p.10) O teatro como prática de educação da criatividade e da expressão dramática é uma das formas de relacionamento teatral entre grupos. Para isso, não necessitam ser particularmente grupos de artistas ou escolares: é uma vivência para todos que, tradicionalmente espectadores, queiram conhecer sua teatralidade, levando-a a uma composição poética [...] Teatro de quem o faz, pessoas de qualquer idade e tarefa profissional (Lopes, 1989, p. 21).

Se em alguns de nós pesquisadores o acréscimo do termo espontâneo pode gerar desconfianças, Lopes logo explicita sua visão bastante crítica: "espontâneo sem ser espontaneísta" (Lopes, 1989, p. 31), buscando uma espontaneidade que evite a "livre expressão condicionada por estereótipos" (Lopes, 1997). Confiante numa práxis de pesquisa-ação contundente e compromissada, Lopes afirma categoricamente: "O melhor caminho para se aprender a jogar é jogando" (Lopes, 1989, p. 16).

Lopes afirma que a capacidade de metamorfose do jogador é o fenômeno básico do jogo dramático espontâneo e

[...] aparecerá como resposta genuína do jogador interessado em transformar-se num outro, o que significa ampliar seu universo de comunicação, capacidade de expressão e criatividade. A metamorfose é o momento em que o indivíduo ultrapassa a si mesmo para elaborar a circunstância e a personalidade de um outro que independe da determinação de sua vontade ideal, interesse e características pessoais, físicas, éticas, morais, econômicas e políticas [...] Através do jogo dramático espontâneo o jogador liga a dimensão estética da vida a todas as outras que definem seu papel e função social.

No exercício dramático, a metamorfose como fenômeno básico requer um crescimento da capacidade de abstração, conceituação e descentralização individual, ou seja, um crescimento em direção à comunicação. Diríamos que quanto mais 
o indivíduo se distancia das evoluções em torno de seu umbigo, mais aumenta seu raio de ação e de sua interferência. Será a metamorfose o sinal deflagrador de cada fase que percebemos no jogo dramático espontâneo, pois é a partir da capacidade de imitar e também da necessidade de fazê-lo que o nosso jogador transmitirá sua relação com o mundo mais próximo e mais longínquo (Lopes, 1989, pp. 61-62).

Preferimos encarar esta questão dos diferentes estágios do jogo dramático que Lopes, na redação realizada em 1973, nomeia como fases evolutivas do jogo dramático, tendo como uma das possíveis referências Piaget (1990) - como uma divisão heurística em que o mais importante é a questão da maturação, do abandono progressivo e voluntário de um egocentrismo. Ao agir como se "eu" estivesse na situação de "outro": "se eu fosse esta outra pessoa, na situação apresentada, o que eu faria?", pouco a pouco o jogador poderia chegar a consentir dentro de si este giro antropológico que exercita a alteridade. O jogador vai cultivando a capacidade de agir em situações ficcionais que talvez não lhe sejam conhecidas ou cotidianas, assumindo atitudes que talvez não lhe sejam habituais. Deste modo o jogador exercita sua potencialidade de "colocar-se no lugar do outro", tratando de compreender pela ação, os desejos e necessidades que movem as pessoas e grupos sociais.

O desenvolvimento da capacidade de metamorfose é um amadurecimento do Ser, não é somente a aprendizagem de máscaras sociais de bom comportamento, cordialidade, formalidade. Adquirir idade não significa necessariamente, adquirir maturidade. Quanto a isto, Lopes afirma claramente: "As etapas evolutivas do jogo dramático não podem ser delimitadas com rigidez, a partir de uma referência cronológica nem podem ser consideradas resultados máximos de um indivíduo" (Lopes, 1989, p. 68). Lopes delineia alguns contornos de estágios de maturação da capacidade de metamorfose, que vão desde as mais simples das brincadeiras dramatizadas (primeiras imitações; fundo de quintal; faz-de-conta), "não sendo um ato consciente do uso e do meio dramático como linguagem" (Lopes, 1989, p. 71) e caracterizadas pela

[...] exteriorização afetiva através de pequenos jogos que simbolizavam a experiência de cada um [...], [onde a] dramatização era um estado de vida interligado com o cotidiano (Lopes, 1989, p. 96).

Se o jogador segue experienciando a expressão dramática e se desenvolvendo nela, pode atingir um grau mais complexo de brincadeira dramatizada (que Lopes nomeia de intenção de realismo e realismo) em que ocorre uma "defasagem entre o que o atuante [jogador] quer expressar e o que ele consegue" (Lopes, 1989, p. 84). É isto que o levará o jogador a buscar aperfeiçoar-se na linguagem. Nestas fases o jogador busca "soluções cênicas a partir da experiência cotidiana" (Lopes, 1989, p. 85).

Se o jogador segue ainda mais cultivando sua expressão dramática, atinge um grau máximo de complexidade que atinge o jogo dramático propriamente dito, como

[...] experiência estética, pois é intencionalmente criada pelo participante com a finalidade de comunicar-se, dar vazão às suas ideias, divertir-se e criar personagens independentes de seu próprio caráter (Lopes, 1989, p. 97). 
No que Lopes nomeia de jogo dramático, a

referência [é] a vida social, e não mais exclusivamente a experiência de vida do participante face à vida social [...] As regras próprias [...] são manipuladas pelos atuantes-atores [jogadores] numa experiência grupal (Lopes, 1989, p. 96).

Parece-me que aí, neste ponto onde se atinge um grau de maturação da capacidade de metamorfose do jogador mais realística (em esclarecimento à qualquer desconfiança que possa associar o que Lopes chama de intenção de realismo e realismo com uma estética realista-naturalista), o jogo dramático observado por Lopes se aproxima da acepção francesa de jogo dramático- jeu dramatique (Pupo, 2005) que o leitor de língua portuguesa teve a oportunidade de tomar contato principalmente por meio de Ryngaert $(1981,2009)$. É quando o jogador passa a ter a percepção da "exigência do espectador como motivação" (Lopes, 1989, p. 96), entendendo o teatro como "opção de linguagem artística" e que o jogo poderá ser "ilusionista ou anti-ilusionista, baseando-se nesses dois modelos clássicos que não são suficientes para enquadrar todas as manifestações que possam ser criadas" (Lopes, 1989, p. 97). Eu incluiria aí nestas outras "manifestações que possam ser criadas" outras formas de expressão dramática: inspiradas no arcaísmo fértil das proto-dramáticas (danças dramáticas populares do Brasil coletadas por Mário de Andrade e colaboradores nas viagens das Missões de 1934) ou pós-dramáticas (como a arte da performance).

Em que estágio de maturação de nossa capacidade de metamorfose nos encontramos neste momento? Diante de diferentes pessoas e diversas circunstâncias nossa atitude é sempre a mesma?

A criatividade e a expressão não são capacidades naturais com níveis inalteráveis, obedecendo à mesma mobilidade e abrangência que a vida do indivíduo possui (Lopes, 1989, p. 59).

O que me interessa discutir é um possível mapeamento da capacidade de metamorfose do jogador, fruto de observações empíricas, ainda que não ignore o que foi relatado e sistematizado por outros pesquisadores e artistas-educadores. Alguns elementos a serem observados já foram elencados: intencionalidade da linguagem; temas recorrentes; desenvolvimento da narrativa e constituição da trama; relação entre jogador e personagem; acordo grupal; modo predominante de expressão; uso de objetos cênicos, cenários, figurinos; ocupação espacial, etc.

Para Slade (1987), o uso do espaço é também um deflagrador de cada etapa da maturação simbólica no jogo dramático infantil. Pela observação de Slade ele reconhece que existem "formas recorrentes" de ocupação do espaço que indicam formas diversas de simbolização das crianças e que

Cada indivíduo desenha o mapa verdadeiro do seu progresso no espaço do chão. É este 'mapa' e sua relação com outras jornadas de outros indivíduos que devemos observar com o máximo cuidado durante os jogos dramáticos, pois isto nos fala em minúcias, como num gráfico, sobre a consecução e realização pessoal e social. [O jogo dramático] é melhor visto e 'lido' de cima (Slade, 1987, p. 23). 
Para Leenhardt a maturação da criança no jogo dramático se relaciona também com a questão da construção da narrativa, da urdidura de uma trama.

Espontaneamente, a criança não sabe construir a sua narrativa, dar-lhe um princípio, um desenvolvimento e um fim, dar-lhe uma progressão dramática. É uma das aquisições que fará por intermédio do jogo dramático.

Diretamente ligada à secura da narração está a pobreza dos diálogos [...]. Mas para que o diálogo encontre o seu verdadeiro lugar de suporte da expressão visual, é necessário que haja jogo e não apenas figuração (Leenhardt, 1977, p. 31).

Estes autores preveem um percurso de maturação no desenvolvimento do jogo dramático espontâneo ou infantil. Além disso, todos ressaltam a importância de a criança ter uma vida social, ter a oportunidade de conviver e jogar com seus pares e propõem, como artistas-educadores, que o jogo seja desenvolvido culturalmente, quando posto em contexto de uma educação sistematizada.

\section{Os jogos de categoria mimicry utilizados num contexto sistema- tizado de educação formal ou não-formal}

Compreendo que os jogos de categoria mimicry experienciados em espaços institucionais, seja de educação formal ou não-formal, não são puramente espontâneos. Surgem propostos pela figura de um professor, educador popular ou artista-educador, que media relações e desempenha o papel de mestre de jogo. Mestre de jogo (Lopes, informação verbal, 1997) designa o artista-educador que propõe ou conduz jogos e dramatizações. A nominação vem da cultura tradicional da infância: o mestre de jogo é, geralmente, uma das crianças mais velhas que toma a liderança nas brincadeiras e cujas outras crianças aceitam sua autoridade: "faremos tudo o que seu mestre mandar". Também no RPG (role-playing games) se utiliza a nomenclatura mestre de jogo.

Como mestre de jogo ou ainda no papel de formadora de outros mestres de jogo passei a ver como de suma importância uma escuta atenta (Ferreira- Santos \& Almeida, 2012). O que me interessa é que seja possível observar, discernir e reconhecer quais são os estímulos mais adequados à cada jogador - ou grupo de jogadores - para que se possa promover uma maturação de sua capacidade de metamorfose.

O fundamental é uma recepção ativa do mestre de jogo em relação às demandas, dificuldades, resistências que surgem por parte dos jogadores antes, durante ou logo após o momento de jogo mimicry. Importa a ampliação da capacidade de expressão dramática como fator importante para que o jogador adquira autonomia sobre "o quê" e "o como" quer expressar-se. Longe de um laissez faire, de uma observação ausente que não se responsabiliza pelo que vê, trata-se aqui de um observatório inicial para que sejam previstos os encaminhamentos que possibilitarão simultaneamente a ampliação da qualidade de expressão na linguagem e uma compreensão de mundo por meio do exercício da expressão dramática.

Cabe então tentar romper com uma dicotomia estanque entre uma abordagem instrumental e outra essencialista (Japiassu, 2003; Desgranges, 2006) na abordagem a pesquisa-ação em teatro-educação. Aqui não interessa defender uma abordagem 
puramente instrumentalista onde a especificidade do jogo dramático é negligenciada em detrimento dos "conteúdos"; ou ainda defender uma abordagem essencialista onde a obsessão pela questão técnica-estética se sobrepõe ao diálogo com o mundo. Não abordo estas duas acepções como contrárias ou excludentes, mas sim como complementares para a criação de uma proposição na confluência destas duas tendências, onde essas duas abordagens de jogo dramático se interpenetram e se retroalimentam. Concordamos com os canadenses Barret e Landier quando afirmam:

[...] optamos deliberadamente por duas vias e duas formas de aprendizagem, indo em direcção ao objetivo do desenvolvimento pessoal que é, acreditamos, o objetivo geral da escola, indo a outra no sentido da sensibilização às práticas artísticas e, em particular, ao teatro (Barret \& Landier, 1994, p. 11).

Acrescentaria que a maturação pessoal, de cultivo da individuação (Jung, 1984) é, a meu ver, o objetivo geral da educação em todo e qualquer ambiente, seja ele escolar ou não. Pois "há vida inteligente fora da escola", como se pode comprovar pelos exemplos positivos de educação popular (Freire \& Nogueira, 1989); educação não-formal (Gohn, 1999), práticas de desescolarização (Iliich, 1977) pululando pelo Brasil e pelo mundo afora. A educação é um modo de proporcionar ao Ser o exercício de realizar o seu potencial humano, sua humanidade, levando em conta seu inacabamento e sua capacidade de auto destinação e recriação de si. Priorizo o "aprender a ser", sobretudo através da experiência e da experimentação como instâncias formadoras, numa proposição ético-poética onde uma educação de sensibilidade (Ferreira-Santos, 2005; Ferreira-Santos \& Almeida, 2012; Duarte-Junior, 2010) se dirige à capacidade de comunicação e expressão do jogador, mas também prevê um transbordamento para a vida, se amplia e verticaliza num trabalho sobre si (Cabrera, 2015) como pessoa.

O jogo mimicry pode levar "à descoberta das relações entre a vida interior e a expressão física" (Santos, 1975, p. 69), num universo onde as sensações, emoções, movimentos e sonoridades são recursos tanto para receber impressões de si mesmo e dos outros como instrumentos para se expressar diante de outros. Por meio de ações o jogador é levado a descobrir "as dimensões vividas e não vividas do seu mundo interior" (Santos, 1975, p. 111). Não se trata somente de aprender códigos ou estéticas, mas de reunir artificialmente condições para que o jogador tenha acesso a uma organicidade que, em muitos casos, não lhe é habitual, que foi esquecida ou perdida (Burnier, 2001).

Interessa englobar, harmonizar e potencializar estes dois pólos de modo que o jogo dramático possa recobrar efetivamente sua intenção civilizatória. Uma abordagem tecnicista e estetizante de jogo mimicry, além de ser desinteressante para jogadores que não buscam profissionalizar-se, é omissa e conivente com a barbárie travestida de consumismo e vazio existencial de nossos tempos. Verifico que, ao cultivar mais amplamente sua capacidade de metamorfose, o jogador pode compreender-se e compreender o mundo numa verticalidade que não lhe seria possível numa abordagem meramente instrumental ou estetizante.

Minha abordagem busca ser mitohermenêutica, isto é, enquanto joga o jogador descobre algo do conteúdo do jogo ao mesmo tempo em que descobre a si mesmo. 
Neste sentido, esta abordagem mitohermenêutica se consolida como uma jornada interpretativa

em que a pessoa é o início, o meio e o fim da jornada e que suscita um engajamento existencial. [...] E aí, então, nessa explosão de sentidos, é que ocorrem as descobertas da constituição de nossa alteridade, numa reconstituição pessoal de sentidos (Ferreira-Santos \& Almeida, 2012, pp. 43-44).

É preciso ressaltar também que, diante de manifestações menos complexas, ainda balbuciantes da expressão dramática, corre-se o risco de uma solução, por parte do orientador, professor, artista-educador de

Considerar o jogo como errado, passando, inclusive, a impor um esquema de trabalho que faça surgir artificialmente os cenários, figurinos e diálogos, que serão estruturados convencionalmente. Isto quebrará, então, a linha evolutiva do atuante [jogador] que começa com o jogo dramático espontâneo e se dirige para o jogo cênico, planejado e elaborado (Lopes, 1989, p. 72).

Já presenciei e presencio bastante ainda estas intervenções cheias de boas intenções mas plenas também de um "pedagogismo" escolarizante, onde são dadas soluções estetizantes "adultocêntricas": de acordo com a estética apreciada pelo adulto, dirigida pela lógica de organização do trabalho exclusivamente do adulto e de acordo com a expectativa de resultados dos adultos. Muitas vezes são dadas soluções aos conflitos entre os jogadores e soluções cênicas advindas de uma mediação diretiva e ostensiva do adulto, que se enxerga como um deus ex machina "colonialista/ opressor" que dirige e estetiza o discurso ainda balbuciante do jogador, sem levar em conta sua necessidade real de discurso.

Por isto, o cuidado em poder mapear entre os jogadores, durante o jogo e por meio do jogo, o que "quer" e "precisa" ser expresso. Este estudo da maturação da capacidade de metamorfose do jogador vem ao encontro desta necessidade de instrumentos de observação que possam viabilizar pouco a pouco um processo em teatro-educação que favoreça a autonomia do discurso do jogador e sua mestria na linguagem dramática.

O jogo vai poder evoluir e construir-se com referências a dois eixos principais de pesquisas e de trabalho: por um lado, a trama dramática vai valorizar-se, a história encontrará sua dimensão; por outro lado, os meios de interpretação e sua qualidade vão ser melhorados dia após dia, sob a direcção discreta do educador e com a participação activa do conjunto do grupo (Leenhardt, 1977, p. 33).

Esta riqueza da expressão dramática espontânea explica a atenção que os educadores lhe prestam e a razão pela qual a consideram essencial ao desenvolvimento harmonioso da criança. Ao revelar a maneira como, de uma forma espontânea, a criança soluciona os seus próprios conflitos e os ultrapassa, a expressão dramática permite, através de uma pedagogia activa e dinâmica, auxiliar e orientar as aquisições e a maturação da criança, sem nada lhe impor de exterior a si própria. Vista deste modo, a função do professor não é ensinar, mas observar e compreender a evolução da criança, após o que sugerirá e encorajará a forma de expressão que lhe parecer mais adequada a facilitar um desenvolvimento. (Leenhardt, 1977, p. 17). 


\section{O jogo dramático com jovens e adultos}

É valioso este estudo do jogo dramático infantil e espontâneo à medida que constato, em minha prática, que o trabalho com jovens e adultos não profissionais do ramo teatral encontra certas características semelhantes ao trabalho com crianças. Ao fim e ao cabo, se trata do ser humano.

Estendo aqui o que eles declaram sobre a maturação da capacidade de metamorfose como algo também verificável no "processo de maturação individual" (Lopes, 1989, p. 65) de adolescentes, jovens e adultos.

Em minha experiência como artista-educadora, na proposição de atividades dramáticas, muitas vezes reconheci que os estereótipos vindos dos meios de comunicação de massa, as personagens esquemáticas e desprovidas de contradição, tramas vindas do cotidiano mais ordinário, diálogos redundantes e uma relação acanhada e formal entre os jogadores eram uma constante. Estas primeiras experiências eram base para a busca de exercícios, técnicas, proposições que pudessem, pouco a pouco, permitir que a qualidade do jogo fosse aumentando e se aprofundando. No início de minha prática como artista-educadora, ao recorrer aos manuais de jogos teatrais mais disponíveis à época e lançados em português (Boal, 1973; Spolin, 1979; Koudela, 2006), pude perceber que se dirigiam a jogadores que tinham atingido certos graus de maturação de sua capacidade de metamorfose como a intenção de realismo e realismo (Lopes, 1989). No caso dos jogos teatrais de Spolin (1979), mais ainda, pois sua premissa é um trabalho preparatório e de criação em improvisação teatral que tende à uma estética realista-naturalista, de cunho predominantemente ilusionista e que auxilia magistralmente o jogador a colocar-se diante do espectador. Spolin desenvolveu os jogos teatrais em um contexto no qual a tradição do texto literário dramatúrgico como ponto de partida para o trabalho atoral ainda preponderava e ela contribuiu para a uma retomada do corpo presente em cena por meio da prática de fisicalização (Spolin, 1979) como ponto de partida para a construção de ações por parte dos jogadores. As premissas fundamentais de Spolin são: "todas as pessoas são capazes de atuar no palco" (Spolin, 1979, p. 3) e "o papel da plateia deve se tornar uma parte concreta do treinamento teatral" (Spolin, 1979, p. 11). Aqui o que se questiona é se um uso indiscriminado do manual seria de valia na formação de crianças, adolescentes, jovens e adultos que não tenham atingido um grau mais complexo de maturação de sua capacidade de metamorfose e que talvez necessitem de outros recursos para alavancar o cultivo desta maturação, anteriores ao grau de complexidade que são como "pré-requisitos" ao que é proposto por Spolin. Tinha, muitas vezes, como pano de fundo de minhas reflexões:

Não apenas de crianças, mas também com adultos que muitas vezes, ao início da prática dos jogos dramáticos, se encontram no mesmo nível expressivo das crianças, pois a sua capacidade de expressão dramática foi bloqueada. (Ela poderá ser retomada contando com as condições atuais do ser adulto, para ultrapassar os esquemas primários de jogo dramático) (Lopes, 1989, p. 67).

Creio que com muitos adolescentes, jovens e adultos também lhes aconteceu algo ao longo deste suposto processo de maturação da expressão dramática: um 
bloqueio, um subdesenvolvimento, um esquecimento. Interessa, diante da situação que se apresenta, nas condições que se apresentam buscar meios para que os processos de simbolização possam ser retomados com as crianças, adolescentes, jovens e adultos. Trabalhando antropologicamente com o conjunto de jogadores, busco favorecer vivências onde o jogador consinta colocar-se em risco, ampliando limitações expressivas e paulatinamente adquirindo autonomia no que quer e como quer dizer seu discurso. A meu ver, as técnicas e estéticas não são um fim em si mesmas.

É por isso que não definiremos a aquisição de uma técnica como anterior à elaboração dum discurso. O fundo não pode ficar subordinado à forma ou visar apenas uma clarificação desta (Ryngaert, 1981, p. 45).

Na busca da elaboração de um discurso é que recorro às técnicas necessárias, nos momentos que se mostram necessários. É importante propor diferentes estímulos técnicos específicos para aquele coletivo, pois cada grupo elabora seu discurso de acordo com quem é e como "funciona". Soluções estetizantes precipitadas interrompem ou obstaculizam o processo de balbucio de uma fala nascente do jogador. Ainda assim, as questões técnicas e poéticas podem nos ajudar a saborear modulações do ser (Merleau-Ponty, 1992).

Interessa aqui, acima de tudo, questionar se aos não profissionais the interessa essencialmente estar num palco, diante de espectadores ou se para eles haveria algo aquém e além deste tratamento espetacular dado ao fazer dramático. Para mim, a afirmação ressoava e ainda ressoa:

O que está por detrás do meu interesse no teatro é ser. O teatro pode ser um espaço para exercer o meu ser? É um espaço-tempo favorável à comunicação mais genuína com o outro? (Cabrera, 2004, p. 151).

\section{A prática de mestre de jogo diante das brincadeiras dramatizadas menos complexas}

Na parte final deste artigo me dedico então a narrar algumas práticas que tentam ser, ao mesmo tempo, uma primeira abordagem ao grupo de jogadores, observando a complexidade de sua maturação da capacidade de metamorfose e práticas de jogo mimicry que podem levar a um discurso articulado.

Como exemplo, tomo uma prática bastante simples, exercitada tanto em grupos de jogadores crianças (entre cinco e dez anos) e também junto a grupos de jovens e adultos (licenciandos em Teatro ou Humanidades e professores). No espaço de trabalho, geralmente uma sala de aula sem móveis, disponho caixas grandes de papelão, bastões de cabo de vassoura, pedaços de corda e elástico, pedaços de plástico-bolha, conduítes, pneus, tábuas, peças de tecidos de cores, texturas e tamanhos diversos, cones, etc. Enfim, os objetos de largo alcance (Leontiev, 2010) ou ainda os materiais não-estruturados (Edwards, Gandini, Forman, 1999), objetos caracterizados por sua plasticidade e que podem ser base para brincadeiras dramatizadas. Disponibilizamos estes objetos, especialmente os de grande porte, para que possam ser usados de acordo com o interesse do jogador, diante do estímulo verbal inicial: $O$ que estes 
objetos podem virar e fazer a gente virar? Todos os jogadores estão no espaço de jogo ao mesmo tempo, todos podem (ou não) manipular os objetos, arriscarem-se.

Presenciei cenas memoráveis de jogadores crianças montando cabanas, empilhando bambus para uma "fogueira de festa junina", arrastando-se sobre o plástico bolha como se nadassem na corredeira de uma cachoeira, brincando "de mentirinha" de bater nas outras com os "macarrões de piscina": poderia dizer que eles estavam exercitando seu jogo de fundo de quintal ou ainda seu faz-de-conta (Lopes, 1989). Presenciei também aquelas crianças e adultos cujo jogo foi além da mera construção de objetos ou de um uso puramente sensorial: dentro das casinhas de papelão viviam papais e mamães, atendiam médicos, usavam-se os objetos iniciais com outros significados, atribuindo-lhes a função de adereços e figurinos. Podia então inferir que estes jogadores tinham "englobado" as fases precedentes da brincadeira dramatizada e naquele momento revelavam um jogo que ia da gradação de faz-de-conta até realismo (Lopes, 1989). Verificava aquilo cuja frase que se atribui a Brecht sintetiza: "há muitos objetos num só objeto". E presenciei também jogos entre os adultos que, num jogo improvisado "de momento", diante do estímulo rítmico de um bastão marcando o compasso no chão, criaram uma belíssima cena de um trabalho de parto, agrupando vários jogadores que foram pouco a pouco encontrando seus papéis no jogo e durante o jogo: gestante, médico, enfermeira, doula, pai, bebê e até placenta fora do útero. Neste caso, se revelou uma maturação bastante grande por parte daqueles jogadores, ao ponto de constituir-se um jogo dramático na acepção francesa (Pupo, 2005, Ryngaert, 2009) e ser de desejo do grupo avaliar o jogo por meio da palavra, desejar refazê-lo e ser capaz de um acordo grupal eficiente que pudesse promover ainda outros aperfeiçoamentos poéticos no discurso. Diante do que via nestas experiências anteriormente descritas com brevidade, pude inferir em quais estágios de maturação da capacidade de metamorfose estava cada um dos jogadores, como a interação (ou não) entre eles os auxiliava a obter (ou não) maior domínio sobre a linguagem dramática durante o jogo, como o uso do espaço e do tempo revelava (ou não) o domínio da linguagem. Não bastava aí analisar o que via, mas sentir-me e receber com todo o meu corpo o que era emitido pelo jogo e pelos jogadores. $A$ postura como mestre de jogo é, no momento do jogo, reagir aos estímulos sem passar, necessariamente, por uma análise mental habitual. A mesma busca que eu tenho como jogadora, como atriz, como mãe: buscar o diálogo com o estado de ser selvagem (Ferreira-Santos \& Almeida, 2012), o pré-reflexivo merleau-pontyano: totalidade da percepção que depende da minha atenção para que o mundo penetre em $\mathrm{mim}$ por meio dos sentidos e se propague em movimentos, sentimentos e ações. Num momento posterior ao jogo, me propunha então pensar quais estratégias, exercícios, proposições faria num encontro seguinte, diante do que eu tinha presenciado do desejo de comunicar e expressar dos jogadores.

A base do trabalho diante de um grupo novo ou de um grupo que revela encontrar-se num estágio de maturação menos complexo da capacidade de metamorfose é a improvisação coletiva sem olhar exterior (Ryngaert, 1981). Esta é uma prática narrada por Ryngaert, mas presente em outras abordagens do ensino da expressão dramática, onde "a partir de uma proposta simples [...] jogar sem qualquer constrangimento e pelo simples prazer de jogar" (Ryngaert, 1981, p. 82). Em minha práxis com 
crianças, adolescentes, jovens e até adultos esta modalidade serve como tentativa de desbloqueio de uma inibição por parte dos jogadores diante do "abismo aterrador" que é a autoconsciência de que "estão me assistindo". Este "abismo aterrador" é algo vivenciado, em muito menor grau, mesmo por profissionais das artes e espetáculos. As reações ao "dever de expor-se" podem ser bastante danosas às pessoas em todas as idades e podem resultar em diferentes manifestações exteriores. No jogador iniciante as mais frequentes são a paralisia; emprego de recursos estereotipados; ausência de organicidade nos movimentos e ações; apressamento ou pouco desenvolvimento da interação entre os jogadores, na criação do diálogo e na contrução da narrativa; personagens esquemáticas, etc. Nos profissionais das artes e espetáculos também surgem manifestações, estas algumas vezes "aceitas no meio profissional" e até sub-repticiamente admiradas por alguns: exibicionismo; emprego estetizante ou repleto de convencionalismos de recursos técnicos que não estão a serviço da construção de um discurso; competividade medida pelo desempenho mais aclamado. São todas manifestações exteriores que, se não são unicamente despertadas nos profissionais pelo "dever de expor-se", tem nele parte de sua origem.

Expor-se, ousar comunicar-se é da natureza intrínseca do teatro (e também do jogo mimicry, em certa medida). Mesmo os jovens e adultos educadores e artistas-educadores em formação inicial com os quais trabalhamos também necessitam aprender a exporem-se, diante da iminência de seu exercício profissional. Talvez sejam poucas as profissões ou atividades onde não se requeira a exposição diante dos outros. O que questiono é o "como" se olha, a "partir de onde" se olha, "para quê" e o "porquê" se olha. Em minha práxis, que algumas vezes arrisca pedir uma exposição da intimidade do jogador ele-mesmo, é preciso respeitar um pudor natural e até sensato por parte de todos os jogadores.

Lidar com algo que parece incompatível com o fazer teatral: o pudor. O pudor protege o que é delicado, indizível, íntimo diante dos olhos vorazes do espectador. Como posso usar o pudor que sinto como uma força? (Cabrera, 2004, p.74).

Assim, proponho em distintas ocasiões durante o curso dos encontros, práticas de improvisação coletiva sem olhar exterior. Não só nos primeiros momentos dos primeiros encontros, mas também em momentos intensos e verticais de trabalho onde nos interessa que o jogador, em seu trabalho sobre si, possa permitir-se revelar "recônditos esquecidos ou perdidos" de si mesmo (Burnier, 2001). Preservar (-se) do olhar do outro serve, então, como recurso de proteção à intimidade, de respeito a um pudor que consideramos benéfico à medida que fortalece a confiança do corpomemória (Grotowski, 1993) para revelar-se ao jogador. Há momentos imponderáveis, profundos, mais próximos de uma manifestação genuína que precisam ser protegidos e encorajados, situações nascentes e delicadas. Como mestre de jogo percebo que é como tomar no colo um bebê recém-nascido, uma presença viva e delicada que nos desperta uma atenção calorosa e sensível, um curvar-se diante do mistério de uma vida nascente. Não se pode percrustrar o outro assim sem que haja muita confiança e cumplicidade. É mais proveitoso tentar trabalhar juntos, simultaneamente, ressoar em sinergia do que tentar assistir somente com os olhos. O mestre de jogo se arrisca 
junto com os demais participantes, mas isto requer dele uma atenção mais ampla, que engloba inclusive o fazer dos outros enquanto ele mesmo faz. Não é algo a ser tentando sempre, é preciso avaliar muito bem quando, com quais pessoas, em que condições serão tentadas com responsabilidade. Mas desta tentativa vimos nascer, algumas vezes, uma relação de confiança mútua entre os jogadores e entre mestre de jogo e jogadores, favorecendo uma rede afetiva.

Entretanto, em minha práxis com a tipologia da improvisação coletiva sem olhar exterior o mestre de jogo segue conduzindo a duração do jogo e as improvisações são feitas individualmente, com todos ao mesmo tempo. Daí surge a necessidade de que todos comecem ao mesmo tempo e terminem ao mesmo tempo.

Às vezes é possível, como mestre de jogo, uma intervenção do jogo pelo jogo (Lopes, informação verbal, 1999-2001; Ryngaert, 2009), durante o jogo enquanto ele acontece, e com um comando mais lúdico. Outras vezes se faz necessário recorrer a um exercício técnico; outra vez o grupo talvez demonstre interesse em avaliar com palavras o jogo realizado. Ao buscar uma recepção ativa diante do jogo, buscando eu mesma estar em estado de jogo, pude vislumbrar encaminhamentos, na tentativa de seguir auxiliando o jogador ou grupo de jogadores a cultivar sua capacidade de metamorfose.

Em minha práxis também está presente a tipologia onde alguns jogadores se sentam e assistem enquanto outros jogam no meio do círculo. Em alguns momentos, metade dos participantes joga individualmente, mas ao mesmo tempo, enquanto a outra metade assiste. Em outros momentos pequenos subgrupos se revezam em jogo coletivo enquanto os demais subgrupos de jogadores assistem. Nesta tipologia o pedido é que o jogador-espectador exercite um olhar atento e aberto, esteja buscando compreender a narrativa por meio dos modos que aqueles jogadores que estão no meio do círculo a estão compreendendo. O mestre de jogo pode propor desafios aos jogadores enquanto estes jogam ou pode modificar ligeiramente como propor o jogo nas rodadas seguintes, de modo que quem está assistindo possa acompanhar variações e uma tentativa de aprofundamento do discurso. Nos jogos onde há a divisão entre quem assiste e quem joga há o interesse em desenvolver nos participantes sua capacidade de produtores e de receptores de uma comunicação. Mas não se trata de verificar, a cada rodada, se houve codificação/decodificação do jogo dramático (Ryngaert, 1981). Interessa mais que pela justaposição de diferentes tentativas individuais ou em subgrupos, todos os participantes, incluindo o mestre de jogo, possam se beneficiar de diferentes pontos de vista, experiências, compreensões da expressão dramática e do que ela permite comunicar. Quanto mais o coletivo compreende a linguagem dramática por meio de suas próprias experiências, mais pode crescer em qualidade de compreensão e elaboração de um discurso. E vice-versa.

Dentre as tipologias elencadas por Ryngaert aquela que é a mais frequente entre os jovens e os adultos, atualmente, é a de jogar um texto não dramático. Minha opção tem sido nos últimos anos pela dramatização de contos filosóficos (Cabrera, 2015). Contos filosóficos (Carrière, 2004, 2008) é uma expressão para designar contos de várias tradições orais (hindu, zen, sufi, hassídica). Contos concisos que transmitem de forma direta o conhecimento acumulado pelos seres humanos em seu processo civilizatório, em determinada cultura, numa leitura de suas camadas e dimensões 
verticais mais profundas.

Para mim a narrativa de contos filosóficos "é apenas um ponto de partida, mas já rico e poético, diferente dos temas habituais de improvisação" (Ryngaert, 1981, p. 111). São contos cujo universo temático e o desenrolar da trama são bastante abertos, não pretendem ser puramente fantasiosos mas, ao mesmo tempo, tem um compromisso com o desconcerto da lógica cotidiana e habitual, da suposta "realidade". Estes contos não incitam uma abordagem obrigatoriamente realista, mas vão, pouco a pouco, auxiliando os jogadores a se exercitarem em ações realísticas, sem necessariamente obrigar a uma estética ilusionista. Estes contos podem ser úteis para alavancar o trânsito de jogadores ou grupos de jogadores que manifestam intenção de realismo e realismo (Lopes, 1989) mas que não trafegam completamente ainda pelo jogo dramático como linguagem. Outras propostas neste sentido de alavancar o jogo com intenção de realismo e realismo com uma estética anti-ilusionista constam também em Barret \& Landier (1994) e em Ryngaert (2009).

No caso de minha práxis, estes contos filosóficos são entendidos como ponto de partida, como base concisa e direta para que o mestre de jogo possa fazer propostas de jogos mimicry que saturam, condensam, estendem no tempo, extrapolam as pulsações presentes na narrativa original. Mas evita-se ao máximo desviar, perverter, "inventar" algo não condizente com os ensinamentos já intrínsceos à narrativa original. Não se trata de "respeito museológico", mas de um cuidado por não rebaixar a qualidade dos contos a uma interpretação precipitada e ordinária. Os contos filosóficos escolhidos até agora são contos que versam sobre o encontro entre mestres e discípulos, diferentes formas em que o processo de ensino/aprendizagem acontece na vida cotidiana. Acredito que os ensinamentos contidos nestes contos de tradição oral possam ser bastante pertinentes e úteis a uma compreeensão mais ampla por parte dos educadores e artistas-educadores em formação do que é o ofício escolhido por eles.

\section{Conclusão}

Como conduta ético-poética na práxis de dramatização (Cabrera, 2015) vejo como fundamental que o mestre de jogo possa reunir condições para a maturação da capacidade de metamorfose do jogador. Sempre com a clareza de que a formação técnica vem das necessidades de elaboração de um discurso (Ryngaert, 2009), não a precede, especialmente com não profissionais.

O interesse por buscar outras formas de observação e de condução na prática de jogo mimicry se deu pelo fato de verificar a existência de gradações na capacidade de metamorfose de jogadores de variadas idades e na percepção de que nem sempre os manuais e técnicas teatrais mais correntes no Brasil nas últimas décadas levam em conta as impossibilidades momentâneas e dificuldades de implantação junto às crianças - e até mesmo aos adultos - de procedimentos consagrados e convencionados no jogo dramático (em suas variadas acepções) e no jogo teatral. É possível a pessoa aprender a responsabilizar-se por seus atos diante do coletivo, é possível aprender a considerar ao outro, colocando-se no seu lugar e virtualmente encarando seus pontos de vista. É possível aprender a realizar e cumprir acordos grupais, sacri- 
ficando pontos de vista exclusivistas, finalistas e ego centrados. É possível saborear a alegria de criar e conservar algo no coletivo, adquirindo compreensões que cada um separadamente seria incapaz de fazê-lo. É possível jogar o jogo mimicry atuando cada vez mais com clareza e intencionalidade na linguagem. Mas todo este aprendizado é fruto de um trabalho intencional de condução por parte do artista-educador tomando como base o aprendiz tal como ele é, não como ele "deveria ser", segundo uma perspectiva alheia aos próprios fatos e circunstâncias. O que busquei discutir brevemente neste artigo é um dos possíveis caminhos para que este processo de maturação se dê por meio de estratégias descolonizadoras e que requerem a autonomia de todos os participantes do processo. Para que o mestre de jogo possa realmente colocar problemas concretos e adequados à cada jogador ou grupo de jogadores, é preciso dar um passo atrás, colocar-se no entre parênteses fenomenológico, na époché husserliana que poderá permitir-lhe discernir qual é o melhor caminho epistemológico a seguir, numa metodologia pedagógico-artística que se desvenda à medida em que o jogo é jogado e que, nem por isso, prescinde dos manuais, que podem e devem ser recuperados e utilizados à medida em que se façam realmente necessários. Mas, mais do que isto, interessa contribuir para um olhar mais atento e sensível diante das manifestações das brincadeiras dramatizadas de crianças, adolescentes, jovens e adultos na contemporaneidade, nestes primeiros balbucios que muitos de nós estarão fadados a conformar-se com o seu não-cultivo ou ainda seu "subdesenvolvimento". Explico-me: diante de uma realidade brasileira contemporânea nos centros urbanos, cada vez menos as crianças brincam livremente, tem espaço e tempo para a brincadeira espontânea. Desse modo, as oportunidades de jogar o jogo de categoria mimicry são menores e, se surgem, são conduzidas de modo ostensivamente diretivo, estetizante e tecnicizante. Parece-me que poucas condições são dadas ao jogador iniciante para que ele possa aprender a jogar com autonomia entre seus pares, lidando com os conflitos intrínsecos ao desafio da convivência social, do aprendizado de respeito às diferenças, do desafio real de estabelecer um acordo grupal. A mediação do artista-educador pode acabar trazendo um "efeito rebote" onde, ao invés do aprendizado da auto-gestão, o grupo pode tornar-se totalmente dependente da condução alheia de um professor de teatro - ou de "Artes", "Educação Artística"- que não chega a fazer parte do grupo, não se envolvendo como artista e como ser humano num processo criativo. Vejo como um dos maiores legados das experiências da Escolinha de Arte do Brasil e do Movimento Escolinhas de Arte do Brasil a postura do artista-educador de pesquisar com a criança, onde a mediação e o registro do conhecimento se fazem durante e por meio do fazer artístico.

Se no contexto atual de teatro-educação parece ultrapassada a discussão que dicotomizava "processo" versus "produto" agora me parece urgente discutir uma estetização/ tecnicização precipitada na formação dramática de crianças na primeira infância, crianças e adolescentes. Percebo isto claramente nos licenciandos em Teatro com quem tenho convivido por meio da supervisão de estágios em espaços formais e não-formais de educação. Estes teatro-educadores em formação inicial têm dificuldade em manter um distanciamento daquilo que eles próprios receberam como formação técnica em Artes Cênicas do cotidiano bastante diverso em que se encontram com crianças e adolescentes cujos desafios poéticos e pedagógicos se 
mostram diversos daqueles da profissionalização teatral. O ponto crucial para mim como formadora de mestres de jogo é: como o mestre de jogo pode auxiliar, encorajar a criança e o adolescente sob sua mediação a chegar a desejar a sociabilização? Como esta criança ou adolescente pode chegar a necessitar, ele próprio, do acordo grupal? Como ele próprio pode perceber benefícios ao seu autodesenvolvimento quando joga como personagem, o que isto a auxilia a ter uma compreensão mais ampla de si, dos outros e do mundo? Como chegar a propiciar experiências consumatórias (Dewey, 1974) na linguagem dramática que possam transbordar para a vida cotidiana? E principalmente: como o artista-educador pode chegar a contagiar alguém se ele próprio não está pleno destas experiências vividas com todo o seu Ser? Que formação ele próprio tem recebido no curso de Licenciatura em Teatro/ Artes/ Cênicas/ Arte, etc. que o aparta ou minimiza o papel da fruição do fazer artístico como amante (Grotowski, 1993)?

Para aquém e além do jogo mimicry que leva em conta a "exigência do espectador" existem muitas outras "formas intermediárias" de fazer teatro. Estar aquém não significa que se deve menosprezá-las, ignorar sua existência ou importância. Estas gradações de jogo mimicry poderiam ser percebidas, acolhidas e encaminhadas no fazer do teatro-educação -e na formação do licenciando em Teatro/ Artes Cênicas/ Arte. Estas "formas intermediárias" não precisam nem devem esgotar-se em si mesmas, são uma base para um trabalho teatral concomitante ou posterior: podem ser uma preparação e/ou complementação a outras técnicas e poéticas já consagradas, como o jeu dramatique e o jogo teatral. Mas se fizermos um uso alienado ou precipitado dos manuais de jogos dramáticos e teatrais como bíblias sagradas, estaremos inclusive incorrendo no engodo de perversão das intenções originais de seus autores. Ou se recorrermos somente à estetização e à tecnicização que espreitam a formação acadêmica especializada, repetiremos sob outras formas exteriores o conflito explicitado no conto de Rosa (2001), "Pirlimpsiquices". Neste conflito descrito belamente no conto se dicotomiza não somente "produto" versus "processo", mas também autonomia de discurso auto motivado do aprendiz em diálogo com formas exteriores que o aluno "colonizado/ oprimido" precisa reproduzir para satisfazer às expectativas de um discurso que corresponda às expectativas do professor "colonizador/ opressor".

No conto do Rosa (2001) o autor-personagem nos descreve, nos momentos finais do conto, a subversão dos aprendizes ao encontrar uma forma de que o "produto" apresentado aos espectadores fosse de fato, resultante de um processo auto motivado e coerente com as necessidades de discurso dos jogadores, autônomos e ousados. Eles vivenciam então aquilo de mais precioso que o jogo de categoria mimicry pode propiciar, aquilo do qual não quero jamais me esquecer e que me faz uma eterna amante (Grotowski, 1993):

Eu mesmo não sabia o que ia dizer, dizendo e dito - tudo tão bem - sem sair do tom. Sei, de, mais tarde, me dizerem: que tudo tinha e tomava o forte, belo sentido, esse drama do agora, desconhecido, estúrdio, de todos o mais bonito, que nunca houve, ninguém escreveu, não se podendo representar outra vez, e nunca mais. Eu via os do público assungados, gostando, só no silêncio completo. Eu via — que a gente era outros - cada um de nós transformado [...] Cada um de nós 
se esquecera do seu mesmo, e estávamos transvivendo, sobrecrentes, disto: que era o verdadeiro viver? E era bom demais, bonito - o milmaravilhoso - a gente voava, num amor, nas palavras: no que se ouvia dos outros e no nosso próprio falar (Rosa, 2001, p. 45-46).

Dedico este artigo à minha primeira mestra, Joana, mão que me guia silenciosa e encorajadoramente, mestra de mestria. Do nosso encontro, meu encontro com uma vocação.

\section{Referências}

BARRET, Gisèle \& LANDIER, Jean-Claude. Expressão Dramática e teatro. Porto: Edições ASA, 1994.

BOAL, Augusto. Duzentos exercícios e jogos para o ator e o não-ator com vontade de dizer algo através do teatro. Rio de Janeiro: Civilização Brasileira, 1983.

BOAL, Augusto. O arco-íris do desejo: método Boal de teatro e terapia. Rio de Janeiro: Civilização Brasileira, 1996.

BOAL, Augusto. Teatro do oprimido: e outras poéticas políticas. Rio de Janeiro: Record, 2005.

BURNIER, Luis Octavio. A Arte de Ator: da técnica à representação: Elaboração, codificação e sistematização de técnicas corpóreas e vocais de representação para o ator. Campinas, São Paulo: Editora da Unicamp, 2009.

Cabrera, Theda. Uma aprendizagem de sabores: a palavra construída a partir da conexão entre movimento, emoção e voz. Dissertação (Mestrado) - Instituto de Artes Universidade Estadual de Campinas. Campinas/ SP: 2004.

Cabrera, Theda. A ético-poética do trabalho sobre si por meio da dramatização de contos filosóficos com mitema iniciático na formação inicial de educadores. Tese (Doutorado) - Faculdade de Educação- Universidade de São Paulo. São Paulo: 2015.

CAILLOIS, Roger. Os Jogos e o Homem: a Máscara e a Vertigem. Lisboa: Cotovia, 1990.

CARRIÈRE, Jean-Claude. O círculo dos mentirosos: contos filosóficos do mundo inteiro. São Paulo: Ediouro, 2004.

Contos filosóficos do mundo inteiro. São Paulo: Ediouro, 2008.

DEBÉRTOLIS, Karen Sílvia. Brasil Mulher: Joana Lopes e a Imprensa Alternativa Feminista. Dissertação (Mestrado) - Programa de Pós-Graduação em Comunicação e 
Informação, Universidade Federal do Rio Grande do Sul. Porto Alegre: 2002.

DESGRANGES, Flavio. A Pedagogia do teatro: provocação e dialogismo. São Paulo: Editora Hucitec/ Editora Mandacaru, 2006.

DEWEY, John. A Arte como experiência. São Paulo: Abril Cultural, 1974.

DUARTE-JUNIOR, João Francisco. O Sentido dos Sentidos: A Educação (do) Sensível. Curitiba: Criar Edições, 2010.

EDWARDS, Carolyn, GANDINI, Lella, FORMAN, George. As cem linguagens da criança: a abordagem de Reggio Emilia na educação da primeira infância. Porto Alegre: Artes Médicas Sul, 1999.

FERREIRA-SANTOS, Marcos. Crepusculário: conferências sobre mitohermenêutica \& educação em Euskadi. São Paulo: Editora Zouk, 2005.

\& ALMEIDA, Rogério. Aproximações ao Imaginário: bússola de investigação poética. São Paulo: Editora Képos, 2012.

FREIRE, Paulo \& NOGUEIRA, Adriano. Que fazer: teoria e prática em educação popular. Petrópolis, RJ: Vozes; 1989.

GOHN, Maria da Glória. Educação não-formal e cultura política. São Paulo: Cortez, 1999.

GROTOWSKI, Jerzy. Número Especial de Homenaje: Grotowski. Máscara- Cuaderno Iberoamericano de Reflexión sobre Escenología. México, ano 3, n. 11-jan. 1993.

HUIZINGA, Johan. Homo Ludens: o jogo como elemento de cultura. São Paulo: Editora Perspectiva, 1999.

ILLICH, Ivan. Sociedade sem escolas. Petrópolis, RJ: Editora Vozes, 1977.

JAPIASSU, Ricardo. Metodologia do Ensino de Teatro. Campinas: Papirus Editora, 2003.

JUNG, Carl Gustav. Psicologia do Inconsciente. São Paulo: Editora Vozes, 1984.

Desenvolvimento da personalidade. Petrópolis, RJ: Vozes, 1986.

KOUDELA, Ingrid Dormien. Jogos teatrais. São Paulo: Editora Perspectiva, 2006.

LEENHARDT, Pierre. A criança e a expressão dramática. Lisboa: Editorial Estampa, 1977.

LEONTIEV, Alexis. Os princípios psicológicos da brincadeira pré-escolar. In: Lingua- 
gem, desenvolvimento e aprendizagem. São Paulo: Ícone Editora, 2010.

LOPES, Joana. Pega Teatro. Campinas: Papirus Editora, 1989.

O Teatro Antropomágico: Dança-Som-Palavra. Tese para concurso para Professor Artista Pleno do Instituto de Artes, Departamento de Artes Corporais, Unicamp, 1997.

MATE, Alexandre. "Apontamentos bibliográficos sobre jogos teatrais no Brasil: Retrospectivas e lutas, conquistas, retrocessos, impermanências". In: Fênix - Revista de História e Estudos Culturais, Vol. 7, Ano VII nํ⒈- Janeiro/ Fevereiro/ Março/ Abril de 2010. Disponível em: www.revistafenix.pro.br, acesso em 15/06/2016.

MERLEAU-PONTY, Maurice. O visível e o invisível. São Paulo: Perspectiva, 1992.

MOUNIER, Emmanuel. O personalismo. São Paulo: Martins Fontes, 1976.

PIAGET, JEAN. Formação do símbolo na criança: imitação, jogo e sonho, imagem e representação. Rio de Janeiro: LTC, 1990.

PUPO, Maria Lúcia de Barros. Para desembaraçar os fios. Educação \& Realidade. São Paulo, vol. 30- pp.217-228- jul/ dez 2005.

RYNGAERT, Jean-Pierre. O jogo dramático no meio escolar. Coimbra: Centelha, 1981. Jogar, representar: práticas dramáticas e formação. São Paulo: Cosac \& Naif, 2009.

ROSA, João Guimarães. Pirlimpisiquices. In: Primeiras estórias. Rio de Janeiro: Nova Fronteira, 2001.

SANTOS, Amicy. Persona: o teatro na educação, o teatro na vida. Rio de Janeiro, Eldorado Tijuca, 1975.

SLADE, Peter. O Jogo Dramático Infantil. São Paulo: Summus, 1987.

SPOLIN, Viola. Improvisação para o teatro. São Paulo: Perspectiva, 1979.

Jogos Teatrais no livro do diretor. São Paulo: Perspectiva, 1999. Jogos Teatrais: o fichário de Viola Spolin. São Paulo: Perspectiva, 2001.

Recebido em: 12/07/2016 Aprovado em: 11/10/2016 